\title{
Blending Adaptive Learning Technology Into Nursing Education: A Scoping Review
}

\author{
Bjarke Linds $\varnothing$ Andersen \\ University College Absalon, Denmark \\ ORCID: 0000-0003-4214-9789 \\ Rasmus Leth Jørnø \\ University College Absalon, Denmark \\ ORCID: 0000-0003-4269-5536 \\ Anne-Mette Nortvig \\ University College Absalon, Denmark \\ ORCID: 0000-0002-7537-0888
}

Received: 6 Aug 2021

Accepted: 26 Sep 2021

\begin{abstract}
Background: Adaptive and personalized learning technologies are on the rise in health education. However, to reach the potential of these technological innovations, novel learning designs are necessary, which take new possibilities and constraints into account.

Aim: In this scoping review we answer the question: What characterizes learning designs where adaptive learning technologies have been blended into nursing education?

Methods: Using the terms adaptive learning and nursing education with synonyms in combination, a comprehensive search in five databases were conducted. Initial search identified 340 records. 22 articles were identified as relevant and screened in full text reading and included. Final number of papers included in the review was six.

Conclusion: We conclude that duration, engagement, placement of interaction in time and agency are the most commonly addressed parts of the learning design. We also find that there is a lack of pedagogical justification of the learning designs used.
\end{abstract}

Keywords: computer-assisted instruction, nursing education, programmed instruction, self-directed learning, adaptive learning

\section{INTRODUCTION}

With rapid advances in machine learning, artificial intelligence and big data, the potentials of educational technology changes in equal measure. A particular example of this is the new trend of 'adaptive learning technologies' (ALT), and 'technology-enhanced personalized learning'. Such educational technologies aim to use input data from students to present content to be learned in a way that best suits the learners' specific needs and conditions.

In the context of health professions' education, ALT have also gained ground, particularly in medical education and in further education. A recent meta-analysis hereof concludes that the adaptive learning technologies seem to have a positive impact on the desired learning outcomes (Fontaine et al., 2019). Thus, 
there is reason to believe that adaptive learning technologies will become a more widespread kind of learning resource in nursing education in the future.

However, research within the field of education technology has also repeatedly shown that the impact of technology cannot be separated from the teaching strategies and learning design, with which it is used (Kirkwood \& Price, 2013). With adaptive learning technology, the technology holds the potential to substitute and augment the actions of the human instructor in some regards: it asks questions, the students respond and the technology provides personalized explanations, if the students are unable to answer correctly. This raises a question about the best way to integrate ALT into nursing education with learning of both clinical, procedural skills and declarative knowledge? Should it be considered just a replacement of the textbook? Is it a new kind of continuous testing system? How do the instructors make the most of the data and content provided by the technology? How do instructors make sure that adaptive learning technology relates to and ensures a transfer from declarative knowledge to clinical practice? In this review, we provide an overview of key features and factors to address in learning design of nurse education with ALT. We draw on the concept of learning design, which explicitly addresses how learning and education is arranged with the use of technology, and draws particularly attention to the sequential structure and supposed actions of instructors and students. A learning design is defined as: "[...] a representation of what happens in a teaching and learning session to help learners achieve specified learning outcomes. It is often structured as a sequence of learning activities that can be shared with others. For online and blended learning, this approach is able to show, not only what is happening when the teacher is with the learners, but also what learners should be doing when the teacher is absent and they are being supported by technology" (Laurillard et al., 2018, p. 1046).

In this review we identify papers that describe the learning design of their interventions in nursing education with ALT. The scope of the review is to identify and discuss how the technology pedagogically is blended into the learning design to support and inform practice by addressing the research question: What characterizes learning designs where ALT have been blended into nursing education?

\section{THE REVIEW}

\section{Aim}

The aim of this review is to examine the learning design through which ALT have been implemented in nursing education.

\section{Design}

The review has been conducted using the method of scoping reviews. Scoping reviews are distinguished from systematic reviews by having a broader interest of inquiry and being more inclusive in terms of research designs than a systematic review (Arksey \& O'Malley, 2005). This is particularly relevant when researching an emerging field of technology, as studies may draw on different methodological approaches, have different interests of inquiry and yet still reveal findings about how to blend ALT into nursing education. The method of scoping reviews is particularly relevant when it comes to identifying potential gaps and point to directions that future research and practice can benefit from (Arksey \& O'Malley, 2005).

\section{Search Methods}

Databases were searched in January 2021 to identify papers that explored ALT in nursing education. The following databases were searched (hits): CINAHL (39), EBSCO (1), Google Scholar (57), PubMed (11), Scopus (232). The search was conducted in collaboration with a librarian and in accordance with the syntax of each database with a string consisting of:

["adaptive learning" OR "personalized learning" OR "individualized learning" OR "intelligent tutoring system" $O R$ "computer-assisted instruction"] AND [technology OR platform OR system OR technologies OR software] AND ["nurs* education" OR "nursing education"]. 
Thesaurus and indexed keywords were used where appropriate in each database. Furthermore, hand searching of reference lists in included studies was also conducted, returning additional 2 hits.

\section{Search Limits}

The search was limited to English language and peer-reviewed papers published from 2010 to 2021.

\section{Inclusion Criteria}

The papers were included if they met the following three criteria: 1) related to the context of nursing education 2) being about technology that algorithmically adapts to one or more of each student's personal traits such as, e.g., proficiency or learning preferences 3 ) describe principles of learning design or an educational intervention.

\section{Exclusion Criteria}

Papers were excluded if the technology described was not adaptive (e.g. clickers or social media), or the adaption was not related to the students learning process (e.g. adaptive rehabilitation technologies for patient care), or the context was not nursing education (physicians, medicine or continuing education for graduated nurses). Particularly, most of the excluded articles were so, because they did not address the context of nursing education.

\section{Search Outcomes}

Initial search resulted in 340 papers, and 2 additional articles were found through handheld searching. After removal of duplicates, 327 papers remained for screening. Screening of title and abstract was undertaken by first author (BLA) based on the inclusion criteria. After this, 22 full text articles remained for assessment of eligibility. This process was undertaken by first author (BLA) and second author (RL) based on in- and exclusion criteria (exclusion with reasons). The process left 6 articles for qualitative synthesis in the scoping review. 


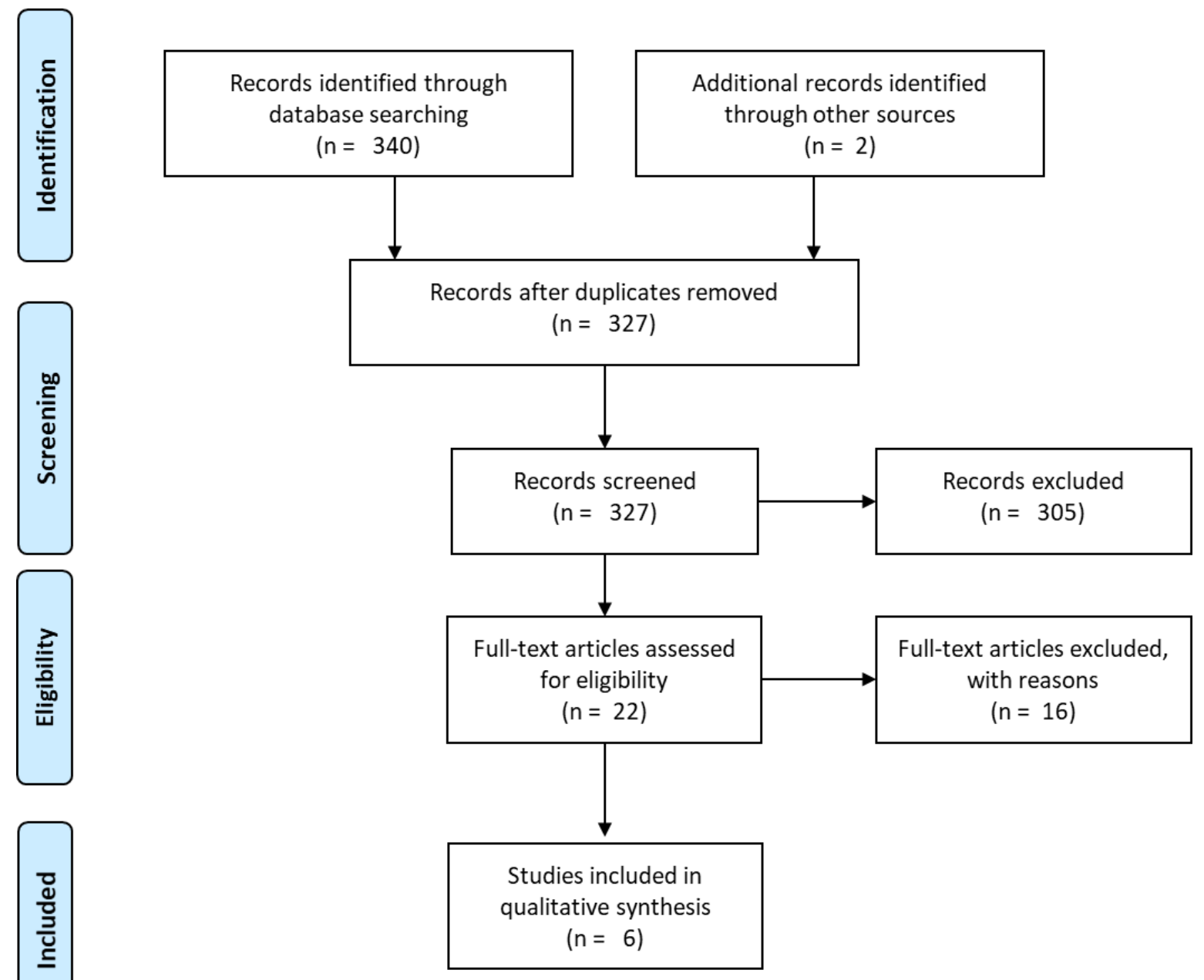

Figure 1. Review process based on Moher et al. (2010)

\section{DATA CHARTING}

In a scoping review, a major concern is to identify and define the variables and themes by which each study is best described in order to address the research question (Arksey \& O'Malley, 2005). By reading the six papers the following six themes have been identified as relevant:

- Motivation for use. What are the hypotheses of impact or desired outcomes of using adaptive technology in nursing?

- Educational context of intervention: What are the institutional and educational contexts in which ALT has been blended in?

- Research methods and data. What methods have been used in the studies and what is the sample size?

- Technological intervention: What characteristics and features of the adaptive technology are highlighted? Learning design intervention: What is the duration and extent of the blend, and what are the explicit and/or implied actions of students and instructors in relation to the use of adaptive technology and how has the course sequentially been built?

- Findings and suggestions: What are the identified potentials of using ALT in nursing education, and what might be addressed in the future?

First, we present a chart with relevant findings from each included articles in a chart and afterwards we discuss relevant findings across the articles. 
Table 1. Data charting

\begin{tabular}{|c|c|c|c|c|c|c|}
\hline Source & $\begin{array}{l}\text { Motivation for } \\
\text { use }\end{array}$ & $\begin{array}{l}\text { Educational } \\
\text { context of } \\
\text { intervention }\end{array}$ & $\begin{array}{l}\text { Research } \\
\text { methods and } \\
\text { sample size }\end{array}$ & $\begin{array}{l}\text { Technological } \\
\text { intervention }\end{array}$ & Learning design intervention & $\begin{array}{l}\text { Findings and suggestions } \\
\text { regarding learning design }\end{array}$ \\
\hline $\begin{array}{l}\text { Hinkle et } \\
\text { al. (2020) }\end{array}$ & $\begin{array}{l}\text { To compare } \\
\text { results with } \\
\text { traditional } \\
\text { methods of } \\
\text { delivery and } \\
\text { assess student } \\
\text { perceptions of } \\
\text { adaptive } \\
\text { learning }\end{array}$ & $\begin{array}{l}\text { Nursing program } \\
\text { in } \\
\text { pathophysiology } \\
\text { in the USA. } \\
2018 .\end{array}$ & $\begin{array}{l}\text { Randomized } \\
\text { control group } \\
\text { experiment. } \\
\text { Intervention } \\
\text { group } \mathrm{n}=35 \text {. }\end{array}$ & $\begin{array}{l}\text { Algorithmic use of real } \\
\text { time data from } \\
\text { student-platform } \\
\text { interaction to } \\
\text { determine the optimal } \\
\text { path through course } \\
\text { content for each } \\
\text { student (Platform: } \\
\text { Realizelt) }\end{array}$ & $\begin{array}{l}\text { 7-weeks of duration online } \\
\text { course. } \\
\text { Questions in AL-platform } \\
\text { were delivered before, during } \\
\text { and after a learning module. } \\
\text { Each AL-module could be } \\
\text { repeated as many times as a } \\
\text { learner chose in order to } \\
\text { improve knowledge, with no } \\
\text { specific engagement } \\
\text { requirements. }\end{array}$ & $\begin{array}{l}\text { Students believe adaptive } \\
\text { learning to improve their } \\
\text { learning and would prefer } \\
\text { adaptive learning in future } \\
\text { courses. }\end{array}$ \\
\hline $\begin{array}{l}\text { Hinkle et } \\
\text { al. (2018) }\end{array}$ & $\begin{array}{l}\text { Enhance case- } \\
\text { based learning, } \\
\text { so that the } \\
\text { complexity of a } \\
\text { case is adjusted } \\
\text { to each } \\
\text { student's } \\
\text { proficiency. }\end{array}$ & $\begin{array}{l}\text { Nursing program } \\
\text { in } \\
\text { pathophysiology } \\
\text { in USA in spring } \\
2015 . \\
\text { Course content } \\
\text { chosen to } \\
\text { specifically } \\
\text { address three } \\
\text { topics of historic } \\
\text { difficulty. }\end{array}$ & $\begin{array}{l}\text { Experimental } \\
\text { study in spring } \\
(\mathrm{n}=95), \\
\text { summer } \\
(\mathrm{n}=22) \text { and fall } \\
(\mathrm{n}=124) \text { in } \\
2015 .\end{array}$ & $\begin{array}{l}\text { Bayesian estimation } \\
\text { techniques that give } \\
\text { each student a } \\
\text { personal path through } \\
\text { course content created } \\
\text { by faculty. Questions } \\
\text { can contain variables, } \\
\text { such as age, and thus } \\
\text { cases presented can be } \\
\text { differentiated for } \\
\text { students (Platform: } \\
\text { Realizelt) }\end{array}$ & $\begin{array}{l}\text { Five sections consisting of } \\
\text { two online, one blended and } \\
\text { one face-to-face. } \\
\text { Case-specific questions were } \\
\text { developed so that they } \\
\text { simulated lab and diagnostic } \\
\text { results that students would } \\
\text { encounter in practice. } \\
\text { Instructor encouraged } \\
\text { students to engage with a } \\
\text { number of "nodes", } \\
\text { comprising an overall topic } \\
\text { objective, but engagement } \\
\text { was not counted as a part of } \\
\text { students' course grade. } \\
\text { Course designed so that } \\
\text { students worked individually. } \\
\text { Instructors supported by } \\
\text { expert instructional designers } \\
\text { in creating content for the } \\
\text { platform. }\end{array}$ & $\begin{array}{l}\text { In terms of engagement, } \\
\text { students tend to engage with a } \\
\text { case-question once or twice } \\
\text { during a course, spending } \\
\text { between } 5 \text { and } 7 \text { minute in each } \\
\text { attempt. Balancing meaningful } \\
\text { case-questions that are not too } \\
\text { taxing is of great importance to } \\
\text { learning design. }\end{array}$ \\
\hline $\begin{array}{l}\text { Morente } \\
\text { et al. } \\
(2014)\end{array}$ & $\begin{array}{l}\text { To determine } \\
\text { the effectiveness } \\
\text { of adaptive } \\
\text { learning } \\
\text { compared to } \\
\text { traditional on- } \\
\text { campus teaching } \\
\text { methods. }\end{array}$ & $\begin{array}{l}\text { Course in } \\
\text { pressure ulcer } \\
\text { training in Spain. } \\
\text { Chosen because } \\
\text { it is considered a } \\
\text { challenging topic } \\
\text { for most } \\
\text { students. }\end{array}$ & $\begin{array}{l}\text { Randomized } \\
\text { control group } \\
\text { study with } \\
\text { pre-test and } \\
\text { post-test. } \mathrm{N}= \\
73 \text { (control } \\
\text { group= 43, } \\
\text { intervention } \\
\text { group = 30). }\end{array}$ & $\begin{array}{l}\text { An adaptive self- } \\
\text { learning e-learning tool } \\
\text { developed by the } \\
\text { research team, which } \\
\text { adapts to the students' } \\
\text { skills and provides } \\
\text { online tutorials } \\
\text { (Platform: ePULab). }\end{array}$ & $\begin{array}{l}\text { 4-hours single session } \\
\text { module, where students were } \\
\text { physically located in a space } \\
\text { with a computer each with no } \\
\text { intervention from the } \\
\text { instructor. }\end{array}$ & $\begin{array}{l}\text { Intervention proved to be } \\
\text { effective, but no findings of } \\
\text { relevance to learning design are } \\
\text { reported. }\end{array}$ \\
\hline $\begin{array}{l}\text { Simon- } \\
\text { Campbell } \\
\text { and } \\
\text { Phelan } \\
\text { (2016) }\end{array}$ & $\begin{array}{l}\text { Prepare } \\
\text { students for } \\
\text { NCLEX license } \\
\text { exam and } \\
\text { optimize } \\
\text { prediction of } \\
\text { students with } \\
\text { likelihood of } \\
\text { failing NCLEX. }\end{array}$ & $\begin{array}{l}\text { Second semester } \\
\text { adult health } \\
\text { course. }\end{array}$ & $\begin{array}{l}\text { Retrospective } \\
\text { descriptive } \\
\text { and } \\
\text { correlational } \\
\text { design. } \mathrm{N}= \\
100 .\end{array}$ & $\begin{array}{l}\text { Online, computer- } \\
\text { based platform with a } \\
\text { large database of test } \\
\text { questions calibrated in } \\
\text { level of difficulty and in } \\
\text { various formats } \\
\text { (multiple choice, fill the } \\
\text { blank etc.). Adapts to } \\
\text { each student's current } \\
\text { level of understanding, } \\
\text { and after finishing the } \\
\text { quiz, the student sees } \\
\text { explanations of key } \\
\text { concepts, answer keys } \\
\text { and results. (Platform: } \\
\text { PrepU). }\end{array}$ & $\begin{array}{l}\text { Students had access to the } \\
\text { system and could choose } \\
\text { between an older and newer } \\
\text { version of the technology. } \\
\text { Attained mastery level was an } \\
\text { important feature to guide } \\
\text { and engage students. No } \\
\text { further description of the } \\
\text { learning design intervention. }\end{array}$ & $\begin{array}{l}\text { Data about students' curricular } \\
\text { weakness can point instructors' } \\
\text { attention to areas that need } \\
\text { focus and remediation in } \\
\text { teaching. For this to happen, } \\
\text { data needs to come timely and } \\
\text { there has to be a clear pathway } \\
\text { to remediation. } \\
\text { Instructors can create class } \\
\text { assignments using collections of } \\
\text { questions chosen for the } \\
\text { database. } \\
\text { Students can independently } \\
\text { take quizzes and train their test- } \\
\text { taking skills. } \\
\text { Policy stating af standardized } \\
\text { use of the technology may be } \\
\text { beneficial. } \\
\text { Create regular, required } \\
\text { assignments or associate a } \\
\text { participation grade with } \\
\text { quizzing activity. }\end{array}$ \\
\hline
\end{tabular}


Table 1 (continued). Data charting

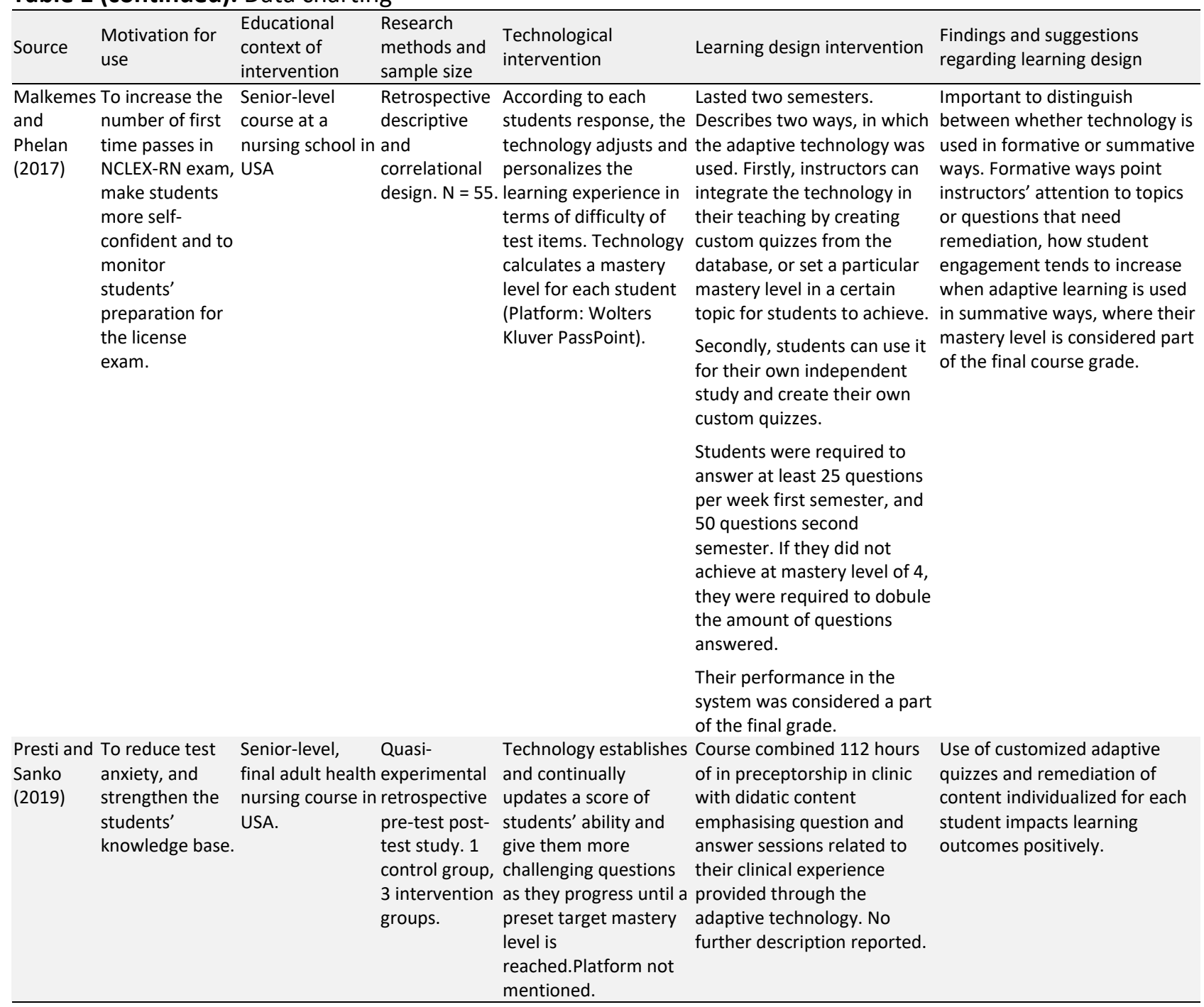

\section{FINDINGS}

\section{Motivation for Use}

There are various reasons for adopting ALT in nursing education. However, two motives are most prominent Firstly, a desire to determine whether ALT improves the learning outcomes compared to traditional teaching methods or not (Hinkle et al., 2020; Morente et al., 2014). Secondly to enhance the likelihood that students pass final license exams (Malkemes \& Phelan, 2017; Presti \& Sanko, 2019; Simon-Campbell \& Phelan, 2016). A single study is pedagogically motivated by a hypothesis that adaptive technologies may provide an enhancement of case-based learning by personalizing cases to the students' abilities (Hinkle \& Moskal, 2018). Reading across the articles, it is evident that the motivation is driven by a summative rather than formative focus in the learning design, i.e., predominantly related to the students' final achievement and to a lesser degree by an enhancement of their on-going learning process.

\section{Educational Context of Intervention}

The questions of geographical origin, subjects and stage are important aspects because the context of intervention determines the degree to which the studies are comparable to other cases and future, and learning design interventions may vary across cultures, subjects and stages within nursing education. Thus, the findings of the articles are embedded in particular cultures of nursing education, set at particular stages 
within the education and tested in disparate subjects. Of the studies that report their geographical origin, five of them are based in nursing education in the USA, and a single in Spain. The subjects in which the ALT has been used are various, and only two state reasons why the specific courses have been chosen. Those two state that the subjects have been chosen for the intervention, because students usually find those subjects particularly difficult (Hinkle \& Moskal, 2018; Morente et al., 2014). Only two studies report at which stage during education, ALT has been used. The two concerned have placed their interventions in the second semester (Simon-Campbell \& Phelan, 2016) and in a final course (Presti \& Sanko, 2019) respectively.

\section{Research Methods}

All of the studies are quantitative with variations in sample size and design, and aimed at calculating the effect of the adaptive technology intervention. Some have control groups and some do not, some have posttest and pre-test and some do not. The experimental nature of all the studies seems to cause a dominance of research design over learning design, and thus the way ALT have been put to use is governed by having a controlled set up rather than arguing and discussing what patterns of use may or may not be beneficial from a pedagogical perspective.

\section{Technological Intervention}

Four of the studies use commercially available software, one uses software developed by the research team (Morente et al., 2014) and one does not report the particular technology used (Presti \& Sanko, 2019). The characteristics of adaptive technology highlighted by each study vary in the level of details by which the adaptive system is described. However, the dominant feature of the adaptive technologies is that they algorithmically determine the proficiency of each student, and based on this generate an individual learning path through the course content. As students improve, they are given harder questions. Some of the technologies used allow students to design quizzes themselves and provide the students with an overall mastery score (Malkemes \& Phelan, 2017; Presti \& Sanko, 2019; Simon-Campbell \& Phelan, 2016).

\section{Learning Design Intervention}

Regarding the learning design of the interventions, it varies how well described it is. In the following, we identify four themes that emerge:

- Duration. The duration of the interventions is one of the most commonly described parameters of the learning design. The duration varies greatly, ranging from a four hour session (Morente et al., 2014) to an experiment that stretches over two semesters (Malkemes \& Phelan, 2017). The remaining studies are somewhere in between and of a length similar to a semester. The length of the intervention may greatly impact the outcome of the use, as longer use time causes familiarization with the adaptive technology, and the novelty effect will eventually decrease. Nursing students currently tend to prefer physical textbooks (Mennenga, 2016), and the introduction of electronic books embedded in a learning technology that dynamically changes according to the students' performance may challenge some of the cultural assumptions and expectations of students. Thus, time to familiarize may be of importance when introducing ALT.

- Placement of student interaction with technology in time. Only two of the studies describe when students were encouraged to engage with the adaptive technology. Hinkle (2020) describes an extensive use, where students were using the adaptive technology both before, after and during class. In Morente, technology was exclusively used in class (2014). Placement of student AL-interaction in time is crucial to the learning design, as it conditions the pedagogical aim of the use. Used before class, it may serve as preparation and provide the instructor with relevant data in which part of the course content to focus on and how to possibly remediate it. Used in class, it may serve as a substitute for teaching by a human instructor in certain parts of the curriculum. Used after class, it may serve as an evaluation tool to assess learning achievement. 
- Engagement. Four of the studies described how they encouraged the students to engage with the ALT. The degree of formalization varies greatly, ranging from Hinkle and Moskal (2018), which had no requirements from the students, and their interactions and achievements were not taken into account to Malkemes and Phelan (2017), who had set criteria for engagement in terms of number of questions to be answered each week, a certain mastery level to be reached and students' performance were taken into account in their final grade. In Hinkle (2018), the instructors continuously encouraged students to use the technology, and in Simon-Campbell and Phelan (2016), it is mentioned that the visualization of progress within the interface was a motivational factor for engagement for students. The extent of student engagement with the technology is evidently of importance to the outcome. In the learning design it is advisable to decide how properly to engage students, whether in terms of weekly activity, a target mastery level or counting their performance as part of final grade.

- Agency. With the key feature of adapting to each student's specific needs or level, the technology also holds a potential to take on some of the work that has previously been that of the teacher: To present content and scaffolding students in their learning process. In two of the studies, the agency and roles of the student, the instructor and the technology are addressed. In Morente et al., technology is used as a substitute for the instructor rendering her or him superfluous (2014). In Malkemes and Phelan, two different modes of agency are described (2017). In the first one, the instructor is assigned the role of a quiz designer, which means the instructor configures the technology by setting a target mastery level, deciding the number of questions to be answered and which parts of the course content the students should engage with. In the second mode, students are themselves given all the privileges described, and thus they obtain the role of conditioning their learning path themselves. None of the remaining six studies address this balance in their intervention.

\section{DISCUSSION}

In this section we discuss the findings and suggestions from the reviewed articles and draw on research from instructional design to expand on future directions of ALT in nursing education. In their meta-analysis of the efficacy of adaptive e-learning among health professionals, Fontaine et. al. concludes: "researchers should focus on research designs allowing the assessment of the impact of multiple educational design variations" $(2019$, p. 15). The studies included in this review echo this point, but also point to specific designs future studies may benefit from exploring. One study (Simon-Campbell \& Phelan, 2016) draws attention to the possibility of informing classroom instruction with data from the students' interactions with the technology, and thus focus on topics and questions, they have found particularly hard. A concern, in this regard, is how instructors properly remediate the content to improve learning in the classroom. Another concern is how to develop a study culture, where students do their 'homework' within the system timely enough for the instructor to take data into consideration before class. This requires that the instructor possesses a certain level of data literacy and is familiar with the technology used as well as its functionalities and interface. In other words it requires competency development of instructors. In the article, Simon-Campbell and Phelan (2016) suggest that policies are demanded to meet this and to set a certain level of engagement from students may be a way to ensure a minimum engagement. Literature on instructional design shows that instructors need to possess a certain technological pedagogical knowledge in order to realize the potential benefits from a given technology. This kind of knowledge is combines knowledge of pedagogy and teaching in a particular subject (e.g., science subjects within nursing education) with knowledge of how the technology works (Mishra, 2016). With ALT this is particularly demanding and important, as adaptive technology has a high degree of complexity in terms of algorithms and computation of data. An increased effort in sharing and developing such knowledge among instructors may positively impact some of the factors highlighted in the papers, such as motivation for use, engagement and the distribution of agency across technology and instructor.

- From the perspective of adaptive learning, a unique feature of nursing education is its combination of declarative knowledge and cognitive skills on the one hand and procedural knowledge and clinical skills on the other. There is evidence, from especially medicine education, that adaptive technology is 
particularly effective in learning cognitive skills and declarative knowledge, whereas the impact on procedural and clinical skills is less clear (Fontaine et al., 2019). This suggests that ALT may be particularly useful in core science subjects and should be integrated in a manner where it partly takes the agency and role of the teacher and the traditional textbooks. Kellman and Krasne (2018) present an approach to combine declarative and procedural knowledge in order to train novices to achieve expert level of recognition and fluency for diagnosis and category learning using adaptive technology. The key is for the students to encounter sufficient variation within and between categories in order to train accurate generalization and recognition of new exemplars. Adopting adaptive technologies for such purposes does not sideline the instructor as "it is the instructor's responsibilities to assist students in understanding the functionalities and the value of the adaptive system" (Cavanagh et al., 2020, s. 186). Rather, the ALT should be viewed as an augmentation and modification of traditional practices (Romrell et al., 2014). As one of the articles point out, adaptive learning may also be useful in customizing patient cases related to learning of clinical skills (Hinkle \& Moskal, 2018) and thus not substitute, but rather augment and modify learning practices. In fact, one of the key features of adaptive learning is that it may free more time for students and instructors to work on clinical skills and procedural knowledge while in the classroom. Drawing on those insights, we suggest that future practices of designing learning with adaptive technologies in nursing education takes point of departure in the following question: Formalia: e.g., What is the duration of the course involving adaptive learning? How many students and teachers are involved? Which parameters are mandated (duration of class, evaluation forms, etc.)?

- What conceptions of learning undergirds the design?

- What are the criteria for engagement, and how are these enforced?

- What courses are deemed particularly well suited for adaptive learning and why?

- What connection between what is learned (and what is not) with the ALT and the face-to-face or synchronous learning is hypothesized?

In future studies of ALT, the learning design could greatly benefit from a larger degree of transparency and explication of the learning design involved, as well as arguments for what subjects adaptive technology are used for and why, and at what stage they are introduced in the course of education. Within the literature of blended learning and flipped classroom in nursing education, such inspiration may be identified (e.g., Cho \& Kim, 2019; Li et al., 2019; Liang et al., 2017; McCutcheon et al., 2015).

\section{CONCLUSION}

In this scoping review, we set out to answer the question: What characterizes learning designs where adaptive learning technologies have been blended into nursing education? Through analysis of the six included papers, we have identified five themes, according to which each article is analyzed. The themes are: motivation, context, methods, technological intervention and learning design intervention. They vary along those five themes, and particularly the learning design is divided into further subthemes, that are worth attending to in instructional design in nursing education. Those are duration of intervention, engagement, placement of interaction in time and the distribution of agency between instructor and AL.

However, it is also evident that the studies reviewed only sporadically describe the learning design of their interventions. We suggest future research and practice with ALT in nursing education addresses the learning design more explicitly. Experimenting with duration, placement of interaction and agency and roles may challenge or complicate conducting experimental research with pre- and post-test as well as intervention and control groups. However, we believe that more qualitative oriented design-experiments may pave the road for identifying new ways of designing nursing education, where the identified potentials of adaptive learning technology are fully realized.

Author contributions: All authors were involved in concept, design, collection of data, interpretation, writing, and critically revising the article. All authors approve final version of the article.

Funding: The authors received no financial support for the research and/or authorship of this article. 
Declaration of interest: Authors declare no competing interest.

Data availability: Data generated or analysed during this study are available from the authors on request.

\section{REFERENCES}

Arksey, H., \& O'Malley, L. (2005). Scoping studies: Towards a methodological framework. International Journal of Social Research Methodology, 8(1), 19-32. https://doi.org/10.1080/1364557032000119616

Cavanagh, T., Chen, B., Lahcen, R. A. M., \& Paradiso, J. R. (2020). Constructing a design framework and pedagogical approach for adaptive learning in higher education: A practitioner's perspective. International Review of Research in Open and Distributed Learning, 21(1), 172-196. https://doi.org/10.19173/irrodl.v21i1.4557

Cho, M., \& Kim, M. Y. (2019). Outcomes and influential factors applying flipped learning methods in a clinical adult nursing practicum. International Journal of Nursing Practice, 25(2), e12724. https://doi.org/10.1111/ijn.12724

Fontaine, G., Cossette, S., Maheu-Cadotte, M.-A., Mailhot, T., Deschênes, M.-F., Mathieu-Dupuis, G., Côté, J., Gagnon, M.-P., \& Dubé, V. (2019). Efficacy of adaptive e-learning for health professionals and students: A systematic review and meta-analysis. BMJ open, 9(8), e025252. https://bmjopen.bmj.com/content/9/8/e025252

Hinkle, J. F., \& Moskal, P. (2018). A preliminary examination of adaptive case studies in nursing pathophysiology. Current Issues in Emerging ELearning, 5(1), 3. https://core.ac.uk/download/pdf/229377185.pdf

Hinkle, J. F., Jones, C. A., \& Saccomano, S. (2020). Pilot of an adaptive learning platform in a graduate nursing education pathophysiology course. Journal of Nursing Education, 59(6), 327-330. https://doi.org/10.3928/01484834-20200520-05

Kellman, P. J., \& Krasne, S. (2018). Accelerating expertise: Perceptual and adaptive learning technology in medical learning. Medical Teacher, 4O(8), 797-802. https://doi.org/10.1080/0142159X.2018.1484897

Kirkwood, A., \& Price, L. (2013). Missing: Evidence of a scholarly approach to teaching and learning with technology in higher education. Teaching in Higher Education, 18(3), 327-337. https://doi.org/10.1080/13562517.2013.773419

Laurillard, D., Kennedy, E., Charlton, P., Wild, J., \& Dimakopoulos, D. (2018). Using technology to develop teachers as designers of TEL: Evaluating the learning designer. British Journal of Educational Technology, 49(6), 1044-1058. https://doi.org/10.1111/bjet.12697

Li, C., He, J., Yuan, C., Chen, B., \& Sun, Z. (2019). The effects of blended learning on knowledge, skills, and satisfaction in nursing students: A meta-analysis. Nurse Education Today, 82, 51-57. https://doi.org/10.1016/j.nedt.2019.08.004

Liang, F., Zhang, P., \& Dou, H. (2017). Effect of flipped classroom on nursing students' learning ability: A meta-Analysis. Chinese Nursing Research, 31(28), 3545-3550. https://doi.org/10.3969/j.issn.10096493.2017.28.017

Malkemes, S., \& Phelan, J. C. (2017). Impact of Adaptive Quizzing as a Practice and Remediation Strategy to Prepare for the NCLEX-RN. Open Journal of Nursing, 7(11), 1289. https://doi.org/10.4236/ojn.2017.711093

McCutcheon, K., Lohan, M., Traynor, M., \& Martin, D. (2015). A systematic review evaluating the impact of online or blended learning vs. face-to-face learning of clinical skills in undergraduate nurse education. Journal of Advanced Nursing, 71(2), 255-270. https://doi.org/10.1111/jan.12509 
Mennenga, H. A. (2016). Nursing student perceptions of digital textbooks: A pilot study. Nursing Education Perspectives, 37(2), 107-109. https://doi.org/10.5480/14-1377

Mishra, P. (2016). Handbook of technological pedagogical content knowledge (TPACK) for educators. Routledge. https://doi.org/10.4324/9781315771328

Moher, D., Liberati, A., Tetzlaff, J., \& Altman, D. G. (2010). Preferred reporting items for systematic reviews and meta-analyses: The PRISMA statement. International Journal of Surgery, 8(5), 336-341. https://doi.org/10.1016/j.ijsu.2010.02.007

Morente, L., Morales-Asencio, J. M., \& Veredas, F. J. (2014). Effectiveness of an e-learning tool for education on pressure ulcer evaluation. Journal of Clinical Nursing, 23(13-14), 2043-2052. https://doi.org/10.1111/jocn.12450

Presti, C. R., \& Sanko, J. S. (2019). Adaptive quizzing improves end-of-program exit examination scores. Nurse Educator, 44(3), 151-153. https://doi.org/10.1097/NNE.0000000000000566

Romrell, D., Kidder, L., \& Wood, E. (2014). The SAMR model as a framework for evaluating mLearning. Online Learning Journal, 18(2), 1-15. https://doi.org/10.24059/olj.v18i2.435

Simon-Campbell, E., \& Phelan, J. (2016). Effectiveness of an adaptive quizzing system to improve nursing students' learning. International Journal of Nursing \& Clinical Practices, 5, 290. https://doi.org/10.15344/2394-4978/2018/290

Correspondence: Bjarke Linds $\varnothing$ Andersen, University College Absalon, Denmark. E-mail: bjan@pha.dk 